\title{
Efektivitas Metode Proyek Dalam Meningktakan Keterampilan Vokasional Membuat Kopi Dari Biji Pepaya Bagi Anak Tunarungu Kelas X Di SLB YPPLB Padang
}

\author{
Siti Fahirah \& Kasiyati \\ Universitas Negeri Padang, Indonesia \\ Email: sitifahirah01@gmail.com
}

\begin{abstract}
This research is motivated by the problem of skills that exist in the YPPLB Extraordinary School Padang. Learning there only teaches sewing skills with the help of teachers and make a variety of skills from used goods and there is no emergence of student motivation because of the way to teach assignments and lecture methods. There are also culinary skills or cooking skills that only teach how to make cakes while making coffee from papaya seeds has never been applied. Based on the researchers' observations there were five deaf students in one class, including four girls and one class X male at the high school level. This research aims to improve vocational skills in making coffee from papaya seeds through the project method. The research method used is pre-experimental design with the type of one group pretest-posttest design. That the research was carried out in several stages namely, the first step of giving initial tests to determine the ability of children. Then given the intervention through the project method. After that it is tested again to see the child's ability after the intervention. Processed data obtained an average of 30.60 in the pre-test and posttest 82.80 using the Wilcoxon sign rank test. The rank test between the pre-test and post-test is 20.23 with Asymp. Sig (2-tailed). Probability that has been set is $a=0.05$. Ha is accepted because the probability <of what has been set is $0.043<0.05$. this proves that the use of project methods is effective in the vocational skills of making coffee from papaya seeds
\end{abstract}

\begin{abstract}
ABSTRAK
Penelitian ini dilatarbelakangi dengan permasalahan keterampilan yang ada di Sekolah Luar Biasa YPPLB Padang. Pembelajaran di sana hanya mengajarkan keterampilan menjahit dengan bantuan guru dan membuat berbagai keterampilan dari barang bekas serta tidak munculnya motivasi siswa karena cara mengajar yang pemberian tugas dan metode ceramah. Selain itu terdapat juga keterampilan tata boga atau keahlian memasak yang cuman mengajarkan cara membuat kue sedangkan pembuatan kopi dari biji pepaya belum pernah diterapkan. Berdasarkan hasil pengamatan peneliti menemukan lima orang siswa tunarungu dalam satu kelas, diantaranya empat anak perempuan dan satu laki-laki kelas $\mathrm{X}$ ditingkat SMA. Penelitian ini bertujuan untuk meningkatkan keterampilan vokasional membuat kopi dari biji pepaya melalui metode proyek. Metode penelitian yang digunakan yaitu pre-experimental design dengan jenis one group pretest-postest design. Bahwasanya penelitian dilakukan dengan beberapa tahap yakni, langkah pertama pemberian tes awal untuk mengetahui kemampuan anak. Kemudian diberikan intervensi melalui metode proyek. Setelah itu dites kembali untuk melihat kemampuan anak setelah adanya intervensi. Data yang diolah mendapatkan hasil rata-rata 30.60 pada pre-test dan post-test 82.80 dengan menggunakan uji wilcoxon sign rank. Nilai rank test antara pre-test dan post-test 20.23 dengan Asymp. Sig (2-tailed). Probabilitas yang telah ditetapkan yaitu $a=0,05$. Ha diterima karena probabilitas < dari yang telah ditetapkan yakni $0.043<0.05$.
\end{abstract}




\section{Jurnal Penelitian Tarbawi: Pendidikan Islam dan Isu-Isu Sosial, Volume 5 No. 12020 Siti Fahirah, Dra. Kasiyati, M.Pd. Efektivitas Metode Proyek}

Hal ini membuktikan bahwa penggunaan metode proyek efektif dalam keterampilan vokasional membuat kopi dari biji pepaya.

Kata Kunci: Metode Proyek, biji pepaya, tunarungu

\section{Pendahuluan}

Ada banyak cara yang bisa dilakukan dalam meningkatkan kualitas sumber daya manusia salah satunya dengan pendidikan. Kita tahu bahwa manusia merupakan makhluk yang sempurna yang memiliki akal dan pikiran, sehingga hal tersebutlah yang membedakan manusia dengan makhluk lainnya. Pemanfaatan akal dan pikiran ini dapat dikembangkan baik melalui pendidikan formal maupun non formal. Hal ini sesuai fungsi dan tujuan yang telah tercantum di UU RI No. 20 Tahun 2003 tentang Sistem Pendidikan Nasional. Dari aturan tersebut dimaknai bahwa siswa tidak hanya memiliki ilmu pengetahuan dan bertakwa kepada Tuhan melainkan dituntut juga untuk mempunyai kecakapan hidup (life skill).

Pembekalan kecakapan hidup berorientasi pada pendidikan vokasional yang mencakup lima jenis: 1) kecakapan mengenal diri, 2) kecakapan berpikir, 3) kecakapan sosial, 4) kecakapan akademik dan 5) kecakapan kejuruan yang ada di sekolah. Kecakapan kejuruan atau keterampilan merupakan suatu kegiatan untuk mengembangkan potensi peserta didik yang sesuai dengan karakternya masing-masing. Pembelajaran vokasional adalah satu mata pelajaran yang diberikan oleh guru kepada siswa dengan tujuan untuk mencapai kemandirian sesuai kebutuhan hidup maupun di lingkungan sekitarnya.

Guru merupakan panutan bagi siswa sehingga harus bisa menentukan strategi dan metode yang cocok terhadap materi yang akan diajarkan pada peserta didik agar siswa tidak cepat merasa bosan ataupun malas. Berbagai metode yang bisa digunakan untuk pembelajaran termasuk metode proyek. Menurut Daryanto, (2009:407) metode proyek yaitu suatu perencanaan dan pelaksanaan pembelajaran yang menekankan pada keterampilan secara individu atau kelompok berdasarkan tujuan yang telah dirancang. Tujuan dari metode ini sebagai berikut: 1). Berfokus pada komunikasi melalui tindakan bernalar. 2). Adanya timbal balik dari materi yang diberikan. 3). Sistem belajar yang luas baik di luar maupun dalam lingkungan. 4). Mengarahkan kemampuan siswa untuk pembaharuan dan pemeliharaan. 5). Mendorong rasa percaya diri dengan memberikan kesempatan pada siswa. Adapun kelemahan dari metode proyek menurut Bielefeld dkk (dalam Khamadi, 2007:50) yaitu : a). Kurikulum yang ada belum bisa menunjang pelaksanaan metode ini. b). Keterkaitan dalam memilih topik untuk peserta didik dengan fasilitas dan sumber belajar yang belum memadai. c). Meluasnya bahan pelajaran yang mengakibatkan ketidakjelasan suatu topik yang dibatasi.

Peneliti telah melakukan obeservasi di SLB YPPLB Padang, di sana terdapat siswa tunarungu yang mana mereka masih mempunyai sisa pendengaran dan tidak memiliki 
hambatan pada motorik kasar maupun motorik halus. Sementara itu siswa tersebut hanya dibekali keterampilan menjahit dengan bantuan guru. Selain itu pada saat pembelajaran sedang berlangung tidak terlihat motivasi yang timbul dari siswa dikarenakan cara mengajar dengan pemberian tugas dan ceramah. Pelajaran keterampilan masih sedikit seperti membuat kerajinan dari barang bekas. Oleh karena itu peneliti tertarik untuk melakukan penelitian membuat kopi dari biji pepaya yang belum pernah diajarkan di sekolah tersebut.

Pepaya berasal dari Amerika Selatan, tepatnya di Meksiko kemudian di budidayakan ke seluruh dunia hingga ke Indonesia. Buah ini memiliki kandungan vitamin a, c, fosfor, kalsium, kalium, protein, bromolin, natrium, zat besi, magnesium, dan serat (Prasetio, 2014). Pepaya telah lama dimanfaatkan untuk membantu mengatasi pencernaan. Manfaat dari biji pepaya berfungsi sebagai antibakteri yang dapat membasmi E coli, salmonela dan infeksi staph. Selain itu ekstrak bijinya dapat melindungi ginjal dan hati dari racun.

Adapun langkah-langkah untuk mengolah biji pepaya menjadi kopi dengan beberapa persiapan seperti menyiapkan alat, bahan, dan proses pengerjaan. Membuat kopi dari biji pepaya tidaklah susah ataupun berbeda melainkan sama cara dengan kopi pada umumnya. Biji pepaya yang sudah ada dicuci lalu di jemur sampai kering dan kemudian disangrai.

Pembelajaran ini sangatlah berguna dan dapat diterapkan kepada anak sejak kecil. Agar anak bisa memahami hal-hal yang baru serta mengembangkan kemampuannya dalam berinovasi. Maka lembaga sekolah harus memberikan berbagai keterampilan kepada semua siswa baik itu dari segi teori maupun praktik yang dapat bermanfaat sehingga menjadi keterampilan yang produktif. Terlebih lagi pada anak berkebutuhan khusus yang bisa menjadi bekal bagi mereka setelah menyelesaikan pendidikan untuk menghadapi tantangan selanjutnya.

Anak berkebutuhan khusus (ABK) merupakan istilah bagi siswa yang memiliki karakteristik yang berbeda pada siswa umum lainnya namun tidak selalu menunjukkan ketidakmampuan fisik, mental, dan emosi. Salah satunya tunarungu atau gangguan pendengaran merupakan bagian dari anak berkebutuhan khusus yang diambil dari kata "tuna" yakni kurang dan "rungu" yaitu pendengaran (Winarsih, 2007). Gangguan pendengaran disebabkan oleh kerusakan fungsi dari sebagian atau seluruh alat organorgan pendengaran yang bisa diketahui dengan menggunakan alat ukur audiometer. Menurut E.koesasi (2012), tunarungu adalah suatu keadaan di mana seseorang kehilangan atau berkurang sehingga membutuhkan alat bantu dengar untuk pendengarannya. Dari pendapat di atas bisa diambil kesimpulan bahwa anak tunarungu adalah seseorang yang mengalami gangguan pada pendengaran baik dialami sejak lahir ataupun karena kecelakaan sehingga disfungsi pada organ telinga berdampak pada kehidupan di lingkungan sekitar. 


\section{Jurnal Penelitian Tarbawi: Pendidikan Islam dan Isu-Isu Sosial, Volume 5 No. 12020 Siti Fahirah, Dra. Kasiyati, M.Pd. Efektivitas Metode Proyek}

\section{Metode}

Pada permasalahan yang terlihat di atas, peneliti menggunakan Pre-experimental design dengan jenis one group pretest-postest design karena desain ini dapat dibandingkan dengan sebelum dan sesudah treatment diberikan kemudian tidak semua perlakuan bisa dikontrol. Metode ini berguna untuk mencoba hal yang belum pernah dilakukan dalam kehidupan masyarakat.

Penelitian eksperimen adalah metode penelitian yang digunakan untuk mencari pengaruh dari suatu perlakuan tertentu terhadap yang lain dalam kondisi yang terkendali. Pendekatan penelitian eksperimen merupakan bagian dari metode penelitian kuantitatif (Sugiyono, 2011:109). Desain penelitian merupakan gambaran dari sesuatu hal yang harus dilakukan dalam penelitian tersebut. Menurut Sanjaya (2013), desain yaitu suatu rancangan yang telah disusun sehingga dapat digunakan dalam penelitian eksperimen dan data yang ditemukan benar-benar akurat kemudian dapat dijadikan bahan dalam rumusan segala generalisasi. Tahap-tahap pelaksanaan penelitian ini, yaitu: 1) siswa tunarungu sebanyak 5 orang yang diberikan tes dalam membuat kopi dari biji pepaya. 2) pemberian perlakuan dengan metode proyek kepada siswa. 3) selanjutnya anak diberikan tes kembali untuk melihat kemampuan akhir.

Pengumpulan data yang digunakan dalam penelitian ini bertujuan untuk mendapatkan hasil yang sesuai dengan yang diharapkan. Teknik pengumpulan data merupakan langkah yang sangat penting pada penelitian sehingga berguna dalam pengumpulan data yang memenuhi standar yang telah ditentukan (Sugiyono, 2016:224). Oleh sebab itu teknik yang digunakan adalah tes perbuatan untuk melihat proses pengerjaan dan mencatat hasil nilai yang dilaksanakan oleh siswa sesuai kriteria yang ditetapkan.

Dalam penelitian ini penulis menggunakan instrumen sebagai alat pengumpulan data untuk mengukur langsung kemampuan awal siswa pada aspek-aspek yang ada di dalam instrumen. Penilaian tersebut dapat diberikan dengan skor yang telah ditentukan.

\section{Pembahasan dan Hasil Penelitian}

Dalam pengolahan data peneliti menggunakan statistik non parametrik. Hal ini disebabkan oleh subjeknya yang kecil kemudian distribusi dan populasi tidak memerlukan uji normatif. Bila sampelnya memiliki ukuran yang kecil dan data yang dipakai bersifat normal serta bentuknya nominal maka ini termasuk kedalam statistik non parametrik. Uji statistik yang digunakan wilcoxon sign rank test untuk menganalisis hasil pengamatan data dari sebelum dan sesudahnya untuk melihat adanya perubahan yang terjadi.

Penelitian dilaksanakan sebanyak tujuh kali pertemuan yang dimulai dari pembukaan pelajaran sampai jam istirahat. Hari pertama peneliti langsung memberikan tes untuk mengetahui kemampuan awal siswa (pre-test). Sementara hari kedua sampai keenam sebagai pertemuan dari intervensi atau pemberian treatment kepada anak. 
Selanjutnya pertemuan terakhir dengan memberikan tes kembali pada siswa sebagai mengukur pengetahuan siswa (pos-test).

Perolehan data yang telah diolah sesuai dengan uji statistik yang telah ditentukan. Didapatkan hasil nilai yang diuji menggunakan aplikasi spss 16. Berikut perolehan skor pre-tes dan pos-tes membuat kopi dari biji pepaya bagi anak tunarungu kelas $X$ di SLB YPPLB Padang.

Tabel 1. Hasil pre-tes dan pos-tes

\begin{tabular}{|c|c|c|c|}
\hline No & $\begin{array}{c}\text { Inisial } \\
\text { subjek }\end{array}$ & $\begin{array}{c}\text { Nilai pre- } \\
\text { tes }\end{array}$ & $\begin{array}{c}\text { Nilai pos- } \\
\text { tes }\end{array}$ \\
\hline 1. & HR & 28 & 85 \\
\hline 2. & AG & 33 & 85 \\
\hline 3. & II & 35 & 90 \\
\hline 4. & DN & 27 & 71 \\
\hline 5 & MT & 30 & 83 \\
\hline & Jumlah & 153 & 414 \\
\hline
\end{tabular}

Dari tabel 1 dapat didefenisikan persentase pretest atau kemampuan awal dan setelah pemberian treatment atau postest.

1. Data nilai pretes

Deskripsi statistik dari nilai pretes

Descriptive Statistics

Tabel 2. Hasil Pretest

\begin{tabular}{|l|r|r|r|r|r|}
\hline & $\mathrm{N}$ & Minimum & Maximum & Mean & $\begin{array}{c}\text { Std. } \\
\text { Deviation }\end{array}$ \\
\hline Pre test & 5 & 27 & 35 & 30.60 & 3.362 \\
Valid N \\
(listwise)
\end{tabular}

Pada tabel 2. Diketahui bahwa nilai tertinggi dari pretes adalah 35 dan nilai terendah adalah 27. Semantara nilai rata-rata yaitu 30.60.

2. Data nilai post-test

Deskripsi statistik dari nilai post-test

Descriptive Statistics

Tabel 3. Hasil Posttest

\begin{tabular}{|l|r|r|r|r|r|}
\hline & $\mathrm{N}$ & $\begin{array}{c}\text { Minimu } \\
\mathrm{m}\end{array}$ & $\begin{array}{c}\text { Maximu } \\
\mathrm{m}\end{array}$ & Mean & $\begin{array}{c}\text { Std. } \\
\text { Deviation }\end{array}$ \\
\hline $\begin{array}{l}\text { Post Test } \\
\text { Valid N } \\
\text { (listwise) }\end{array}$ & 5 & 71 & 90 & 82.80 & 7.085 \\
\hline
\end{tabular}

Dari tabel 3. Dapat dilihat bahwa nilai tertinggi adalah 90 dan nilai terendahnya 71. Sedangkan nilai rata-rata yaitu 82.80 . 
Pada pengujian hipotesis, diperlukan ketentuan dalam analisis data yang menghasilkan adanya bandingan Asymp Sig. (2 tailed) dengan taraf signifikansi (a). Dalam analisis taraf signifikan yang dipakai yakni 0.05 atau 5\%. Di bawah ini adalah tabelnya:

Tabel 4. Syarat pengujian hipotesis

\begin{tabular}{|l|l|l|l|}
\hline \multicolumn{1}{|c|}{ Hipotesis } & $\begin{array}{c}\text { Asymp. } \\
(2- \\
\text { tailed })\end{array}$ & $\begin{array}{c}\text { Sig.Taraf } \\
\text { signifikans } \\
\mathrm{i}(\mathrm{a})\end{array}$ & $\begin{array}{c}\text { Kesimpula } \\
\mathrm{n}\end{array}$ \\
\hline $\begin{array}{l}\text { Ho: } \\
\text { Metode proyek tidak efektif } \\
\text { untuk membuat kopi dari biji } \\
\text { papaya }\end{array}$ & 0.05 & 0.05 & Ho ditolak \\
\hline $\begin{array}{l}\text { Ha: } \\
\text { Metode proyek efektif untuk } \\
\text { membuat kopi dari biji papaya }\end{array}$ & $<0.05$ & 0.05 & $\begin{array}{l}\text { Ha } \\
\text { diterima }\end{array}$ \\
\hline
\end{tabular}

Test Statistics ${ }^{b}$

Tabel 5. Hasil Uji Analisis

\begin{tabular}{|l|r|}
\hline & Post Test - Pre test \\
\hline$Z$ & $-2.023^{\mathrm{a}}$ \\
$\begin{array}{l}\text { Asymp. Sig. (2- } \\
\text { tailed) }\end{array}$ & 0.043 \\
\hline
\end{tabular}

a. Based on negative ranks.

b. Wilcoxon Signed Ranks Test

Bila dilihat dari perbandingan pretes dan postes terjadi peningkatan dalam pengetahuan siswa terhadap vokasional membuat kopi dari biji pepaya. Pada hasil nilai 2.023 yang dibandingkan dengan Asymp Sig. (2-tailed) = 0.043 maka $>$ Asymp. Sig (2tailed) Maka bisa diambil kesimpulan bahwa metode proyek efektif dalam meningkatkan pengetahuan setelah diberikannya perlakuan bagi anak tunarungu.

\section{Kesimpulan}

Berdasarkan hasil dari uraian yang telah dipaparkan hal ini terbukti dari perhitungan data yang diolah dengan menggunakan uji Wilcoxon Sign Rank test dimana 2.023 dan Asymp sig. $(2$-tailed) $=0.043$, nilai taraf signifikan 95\% dan $a=0.05$. Dengan menggunakan aplikasi SPSS 16 diperoleh hasil uji wilcoxon yaitu 0.043 lebih kecil dari nilai probabilitas yang telah ditatapkan 0.05. Pada pengujian hipotesis maka Ha diterima dan Ho ditolak. Jadi dapat ditarik kesimpulan bahwa metode proyek efektif dalam meningkatkan 
keterampilan vokasional membuat kopi dari biji pepaya bagi anak tunarungu kelas $X$ di SLB YPPLB Padang

\section{Daftar Rujukan}

Daryanto. (2009). Panduan Proses Pembelajaran Kreatif dan Inovatif. Av Piblisher.

E.koesasih. (2012). Cara Bijak Menanggani Anak Berkebutuhan Khusus. Yrama Widya.

Khamadi, W. (2007). Pembelajaran Berbasis Proyek: Model Potensial untuk Peningkatan Mutu Pembelajaran. Diakses (01 Agustus 2019).

Prasetio, B. (2014). Membangun Bisnis Olahan Buah Dengan Modal Kecil. Lily Publisher.

Sanjaya. w. (2013). penelitian pendidikan. Prenada Media Group.

Sugiyono. (2011). Metode Penelitian Kombinasi (Mixed Method). (Sutopo, Ed.) (alfabeta).

Sugiyono. (2016). Metode Penelitian Kuantitatif, Kualitatif dan R E D. Alfabeta.

Winarsih, M. (2007). Intervensi Dini bagi Anak Tunarungu dalam Pemrolehan. DEPDIKBUD. 